Website: https://journal.stiba.ac.id

ISSN : 2685-7537 (online); 2338-5251 (Printed)

\title{
TRADISI TE'NEA DALAM PERSPEKTIF HUKUM ISLAM (STUDI KASUS DI DESA MAJANNANG)
}

\section{Te'nea Tradition in the View of Islamic Law Perspective (Case Study In Majannang Village)}

\section{Hendra Wijaya}

Sekolah Tinggi Ilmu Islam dan Bahasa Arab (STIBA) Makassar

Email: abumuslimhwj@gmail.com

\section{Fadlan Akbar}

Sekolah Tinggi Ilmu Islam dan Bahasa Arab (STIBA) Makassar Email: fadlanakbar75@gmail.com

\section{Keywords : \\ Culture, The Te'nea Tradition, \\ Majannang, Islam, Faith.}

\begin{abstract}
The purpose of this research was to identify the description of te'nea tradition, to recognize the driving force behind the shift in the meaning of te'nea tradition, and to explain the view of Islamic law regarding te'nea tradition in Majannang Village, Parigi District, Gowa Regency. The research method employed field research studies with a case study format through sociological and normative approaches. The results showed that te'nea tradition was initially conducted merely with the purpose of kinship and eating together with relatives in an effort to commemorate the ancestors of the Pajaiyya extended family. The shift of the meaning of te'nea tradition occurred due to healing phenomenon of a broken leg sufferer in Bungung Toa where the ritual of te'nea took place. The shift of the tradition of te'nea is very fatal because it is suspected to contain shirk which has implications for the haram of this tradition in the perspective of Islamic Law, but if the element of shirk can be eliminated then this tradition will be in line with the teachings of friendship which is mustahab (recommended). ABSTRAK

Tujuan penelitian ini adalah untuk mengetahui gambaran tradisi te'nea, menemukan faktor pendorong pergeseran makna tradisi te'nea, dan memaparkan pandangan hukum Islam perihal tradisi te'nea di Desa Majannang, Kecamatan Parigi, Kabupaten Gowa. Metode Penelitian menggunakan kajian field research dengan format studi kasus melalui pendekatan sosiologis dan normatif. Hasil penelitian menunjukkan bahwa tradisi te'nea awalnya hanya diselenggarakan dengan tujuan silaturahmi dan makan bersama sanak keluarga sebagai upaya mensyukuri nikmat dan mengenang nenek moyang keluarga besar tau pajaiyya, kemudian berkembang menjadi ajang musyawarah tokoh masyarakat untuk menetapkan apa yang hendak dilakukan di awal musim tanam. Pergeseran atas makna tradisi te'nea terjadi ketika timbul fenomena kesembuhan seorang penderita patah tulang kaki di bungung toa, tempat ritual te'nea berlangsung. Pergeseran tradisi te'nea sangatlah fatal karena ditengarai mengandung kesyirikan yang berimplikasi pada haramnya tradisi ini dalam persperktif Hukum Islam. Namun jika unsur syirik dapat dihilangkan maka tradisi ini akan sejalan dengan ajaran silaturahmi yang sifatnya mustahab(dianjurkan).
\end{abstract} ABSTRACT

Kata kunci :

Budaya, Tradisi Te'nea,

Majannang, Islam, Akidah.

\footnotetext{
Riwayat artikel: Diterima: 18 Maret 2020; Direvisi: 31 Mei 2020; Disetujui: 31 Mei 2020; Tersedia online: 12 Juni 2020 .

How to cite: Wijaya, H., Akbar, F. (2020). Tradisi Te'nea dalam Perspektif Hukum Islam (Studi Kasus di Desa Majannang). NUKHBATUL 'ULUM: Jurnal Bidang Kajian Islam, 6(1), $145-158$. https://doi.org/10.36701/nukhbah.v6i1.102
} 


\section{PENDAHULUAN}

Cultural diversity atau keragaman budaya adalah keniscayaan yang ada di bumi nusantara. Keragaman budaya di Indonesia adalah sesuatu yang tidak dapat dipungkiri keberadaannya. Suku, agama, ras, dan golongan yang beragam, mulai dari Sabang sampai Merauke, menjadikan Indonesia sebagai negara multikultural yang kaya akan tradisi dan adat istiadat. ${ }^{1}$ Tradisi-tradisi yang beragam tersebut juga memiliki berbagai macam tata cara pelaksanaanya, sebagian di antaranya memiliki kemiripan antara satu dengan yang lainnya, bahkan kadangkala tata cara pelaksanaan yang sama namun yang membedakan hanya pada istilahnya saja.

Manusia merupakan makhluk yang berbudaya, melalui akalnya manusia dapat mengembangkan kebudayaannya masing-masing. Begitu pula manusia hidup dan tergantung pada budaya hasil cipta, rasa dan karyanya karena hakikat manusia adalah makhluk yang dapat dididik dan mendidik (homo educandum) untuk mengembangkan suatu kebudayaan dan/ atau peradaban. ${ }^{2}$ Kebudayaan juga memberikan aturan bagi manusia dalam mengolah lingkungan dengan teknologi hasil karyanya.

Budaya merupakan hasil pemikiran dan gagasan yang dijadikan cara hidup yang berkembang dimiliki oleh suatu kelompok dan diwariskan dari generasi ke generasi. Terkadang budaya mengandung arti penting dalam kehidupan bermasyarakat meskipun beberapa kalangan masyarakat menganggap kebudayaan yang dilakukan oleh sebagian masyarakat dianggap bertentangan dengan agama, meskipun kelihatannya religius. Dengan demikian, pada dasarnya diasumsikan bahwa agama mempengaruhi kebudayaan dan kebudayaan cenderung berubah-ubah dalam mana berimplikasi pada keaslian agama sehingga menghasilkan penafsiran berlainan di kalangan masyarakat. ${ }^{3}$

Agama bersumber dari Allah, budaya bersumber dari manusia, tetapi bukan berarti keduanya tidak terkait sama sekali, keduanya memiliki hubungan yang erat. Ajaran agama dibawa oleh para nabi, Allah menyampaikan hakikat diriNya, manusia, alam semesta dan kehidupan yang harus dijalani oleh manusia. Ajaran Allah yang disebut agama, mewarnai corak budaya yang dihasilkan oleh manusia yang memeluknya.

Salah satu budaya yang sampai sekarang masih dipertahankan oleh sebagian masyarakat yaitu tradisi te'nea yang terdapat di Desa Majannang, Kecamatan

\footnotetext{
${ }^{1}$ Lestari, G. (2016). Bhinnekha Tunggal Ika: Khasanah Multikultural Indonesia Di Tengah Kehidupan SARA. Jurnal Pendidikan Pancasila dan Kewarganegaraan, 28(1).

2 Burga, M. A. (2019). Hakikat Manusia Sebagai Makhluk Pedagogik. AlMusannif, 1(1), 19-31.

${ }^{3}$ Bauto, L. M. (2014). Perspektif agama dan kebudayaan dalam kehidupan masyarakat indonesia (Suatu tinjauan sosiologi agama). Jurnal Pendidikan Ilmu Sosial, 23(2), 11-25.
} 
Parigi, Kabupaten Gowa, Sulawesi Selatan. Tradisi ini sudah turun-temurun dilaksanakan oleh masyarakat Desa Majannang.

Desa Majannang merupakan tempat awal mula pelaksanaan tradisi te'nea. Salah satu tokoh utama tradisi ini adalah tau pajjaiya, dia merupakan orang yang pertama kali membentuk Desa Majannang. Kemudian dilanjutkan oleh keturunannya hingga sampai saat ini keturunan ketujuh yang melestarikan tradisi te'nea tersebut.

Tradisi te'nea pada dasarnya dilaksanakan pada saat padi masih muda atau dikenal dengan istilah appasulu' bungasa. Keturunan tau pajjaiya berkumpul di rumah panggung untuk melaksanakan tradisi te'nea. Karena tradisi te'nea hanya bisa dilakukan oleh keturunan tau pajjaiya, artinya hanya keluarga atau keturunan tersebut yang boleh melakukan tradisi ini. Adapun di luar keluarga tersebut hanya boleh ikut makan saja. Dalam tradisi ini ada simbol te'nea yang saling berhubungan yaitu bungung toa (sumur tua) dan guci tau pajjaiya yang terletak di RW. Bajannang Desa Parigi.

Tradisi te'nea sudah mengalami banyak perubahan yang dulunya tradisi ini adalah untuk sarana silaturahmi keluarga besar dan musyawarah di antara semua anggota keluarga dari keturunan tau pajjaiya. Namun, seiring berjalannya waktu, nilai-nilai dari tradisi tersebut mulai menghilang disebabkan adanya pemahaman dan tujuan lain dari pelaku tradisi tersebut. ${ }^{4}$ Bentuk dari pergeseran nilai itu adalah penambahan batang erasa (pohon beringin) sebagai simbol dari te'nea, kemudian bermunculan ritual-ritual tambahan, oleh sebab itu perlu ditelusuri faktor-faktor pergeseran tradisi tersebut sembari dilakukan pengkajian ilmiah dalam pandangan syariat Islam. Maksudnya kajian difokuskan untuk mengetahui, mengungkap, dan menjelaskan ritual tradisi te'nea dalam perspektif hukum Islam.

Dalam melihat novelty (kebaharuan) dari penelitian ini, maka dilakukan trace (penyelidikan) terhadap hasil-hasil penelitian terdahulu yang relevan. Berikut disajikan hasil penelitian terdahulu:

1. Penelitian yang dilakukan oleh M. Misbahul Mujib dalam kajiannya perihal fenomena tradisi ziarah masyarakat Jawa menemukan bahwa pada dasarnya peziarah bertujuan untuk memperlihatkan identitas keagamaannya seiring masih adanya kaum Abangan yang masih belum memahami ziarah dalam perspektif agama sembari adanya kaum agamawan yang menolak adanya pelaksanaan ziarah juga berpengaruh terhadap banyaknya peziarah. ${ }^{5}$

${ }^{4}$ Dg. Sibali dan Dg. Baharuddin Dg. Ngitung, Tokoh Agama, (wawancara langsung pada tanggal 21 Februari 2020).

${ }_{5}^{5}$ Mujib, M. M. (2016). Fenomena Tradisi Ziarah Lokal dalam Masyarakat Jawa: Kontestasi Kesalehan, Identitas Keagamaan dan Komersial. IBDA: Jurnal Kajian Islam dan Budaya, 14(2), 204-224. 
2. Penelitian yang dilakukan oleh Abidin Nurdin ihwal tradisi maulid masyarakat Aceh menunjukkan bahwa dalam tradisi maulod di Aceh terjadi integrasi antara agama dan budaya. Perayaan maulod tidak hanya sebatas satu bulan saja, namun dilaksanakan dalam tiga bulan yaitu, Rabiulawal (mulod awai), Rabiulakhir (mulod teungoh) dan pada bulan Jumadilawal (mulod akhe). ${ }^{6}$

3. Penelitian yang dilakukan oleh Ramdan Wagianto terkait tradisi kawin colong masyarakat Osing menyatakan bahwa faktor penyebab kawin osing, di antaranya adalah tidak disetujui oleh orang tua, nyepetaken lakon, takut lamaran ditolak dan perbedaan status sosial dan tingkat perekonomian, serta dari perspektif Sosiologi Hukum Islam dengan pendekatan teori al-'urf, memandang kawin colong masih tergolong 'urf yang sahih. ${ }^{7}$

4. Penelitian yang dilaksanakan oleh Abdul Karim perihal tradisi kematian masyarakat Jawa menampakkan bahwa ritual kematian yang dilakukan oleh masyarakat Islam Jawa sesungguhnya merupakan adat masyarakat Jawa sebelum masuknya agama Islam, dan tradisi tersebut merupakan akulturasi dari kebudayaan agama Hindu, Budha dan Islam yang secara berkelanjutan di masa lalu. ${ }^{8}$

5. Penelitian yang diterapkan oleh Marinsah, Hamdan, dan Ariffin terkait amalan tradisi masyarakat Bajau menyimpulkan bahwa dalam amalan masyarakat Bajau terdapat banyak unsur sinkretisme antara ajaran Islam dengan adat tradisi sehingga penelitian ini mengupas garis pembeda antara budaya yang selaras dan bertentangan dengan syariat Islam. ${ }^{9}$

Dari hasil penelitian di atas, ditemukan persamaan dari sisi upaya investigasi ilmiah terhadap tradisi-tradisi yang hidup dan dilestarikan di tengah-tengah masyarakat Indonesia, yang telah menjadi sebuah kearifan lokal yang bernilai di kancah dunia (mancanegara). Persamaan selanjutnya adalah dalam penelitian terdahulu telah berupaya mengkaji faktor-faktor pendukung muncul, berkembang, dan lestarinya sebuah tradisi yang hidup di masyarakat. Perbedaan mendasar dari penelitian terdahulu terletak pada objek tradisinya, di mana belum didapati kajian mendalam terhadap tradisi te'nea dalam perspektif budaya secara umum, terlebih lagi dalam perspektif hukum Islam secara khusus.

\footnotetext{
${ }^{6}$ Nurdin, A. (2016). Integrasi Agama dan Budaya: Kajian Tentang Tradisi Maulod dalam Masyarakat Aceh. EL HARAKAH (TERAKREDITASI), 18(1), 45-62.

${ }^{7}$ Wagianto, R. (2017). Tradisi Kawin Colong Pada Masyarakat Osing Banyuwangi Perspektif Sosiologi Hukum Islam. Al-Ahwal: Jurnal Hukum Keluarga Islam, 10(1), 61-84.

${ }^{8}$ Karim, A. (2017). Makna ritual kematian dalam tradisi Islam Jawa. Sabda: Jurnal Kajian Kebudayaan, 12(2), 161-171.

${ }^{9}$ Marinsah, S. A., Hamdan, M. N., Ariffin, M. F. M., \& Ramli, M. A. (2016). Amalan tradisi masyarakat Bajau di Semporna Sabah: kajian menurut hukum Islam. Perspektif: Jurnal Sains Sosial dan Kemanusiaan, 8(2), 135-149.
} 
Untuk kajian keislaman atau pemakaian lensa syariat Islam dalam menimbang tradisi masyarakat sudah dirintis oleh beberapa peneliti terdahulu, sebagaimana yang dilakukan oleh Ramdan Wagianto, Marinsah, Hamdan, dan Ariffin.

Dengan demikian, hasil penelitian ini dapat berkontibusi dalam memperkaya kajian dirasah Islamiyah, khususnya di bidang Hukum Islam di Indonesia.

\section{METODE}

Untuk melakukan investigasi lebih mendalam terhadap fenomena di atas, diperlukan metode penelitian yang mumpuni. Penelitian ini menggunakan metode field research dengan format studi kasus dan memakai pendekatan sosiologis dan normatif dalam mengkaji tradisi te'nea di Desa Majannang.

\section{PEMBAHASAN}

\section{Proses Pelaksanaan Tradisi Te'nea di Desa Majannang, Kec. Parigi, Kab. Gowa}

Pelaksanaan tradisi te'nea di RW. Bajannang, Dusun Nirannuang, Desa Majannang, Kec. Parigi, Kab. Gowa. Tupa'jaiyya diinisiasi oleh pendiri dari kampung di Majannang, kuburannya berada di daerah Bajannang dengan lokasi kuburannya paling tinggi dan ditutup oleh seng. Makamnya bersama atau berdampingan dengan makam suaminya. Ia merupakan orang yang pertama kali melakukan tradisi te'nea, dengan menggunakan guci sebagai simbol dan pusat lokasi pertemuan dengan warga yang lain atau bisa juga disebut orang yang memiliki ilmu saat itu. Mereka menjadikan guci tersebut sebagai tempat minum mereka dikala bersantap. Makanannya pun mereka bawa dan dicuci di bungung toa (sumur tua) yang ada di RW. Putepala. Dengan demikian, asumsinya, tradisi te'nea ini memiliki sangkut paut (keterhubungan) antara guci dan sumur hingga sekarang.

Belakangan ini ada beberapa masyarakat yang menambahkan lokasi untuk melakukan tradisi te'nea ini, yaitu dengan mengunjungi batang erasa (pohon beringin) dan juga ziarah ke Makam Tupa'jaiyya dikarenakan masyarakat hari ini meyakini bahwa jika mereka meminta sesuatu maka akan terkabul. Dengan demikian, diasumsikan telah terjadi pergeseran budaya terhadap tradisi te'nea.

Proses pelaksanaan tradisi te'nea juga dilakukan di sumur tua yang ada di Majannang tepatnya di RW. Putepala, air sumur dipakai untuk cuci bahan makanan sebelum diolah dan dimakan di rumah panggung, ini wajib dilakukan sebelum melakukan pertemuan di rumah panggung. Maka dari itu, rumah yang ditempati guci tersebut berkaitan dengan sumur tua. Acara te'nea hanya bisa diikuti oleh keluarga pemilik hajat, tapi untuk makan bersamanya bisa diundang warga lain di sekitaran kampung tersebut. 


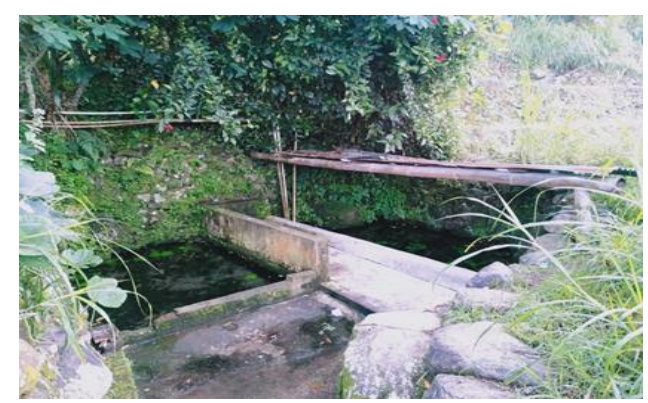

Gambar 1.1. Bungung Toa di RW. Putapela.

Awalnya hanya sebagai ajang silaturahmi dengan guci tersebut sebagai tempat air minum mereka. Asal mula guci sudah ada dari penghuni pertama Desa Majannang, tidak ada ritual khusus sebelum makan bersama. Guci tersebut juga tidak bisa dipindah-pindahkan tempatnya, jumlahnya ada ada empat atau enam buah, salah satunya adalah guci besar yang biasa ditempati air untuk minum. Tinggi gucinya kira-kira $30 \mathrm{~cm}$ dengan warna hijau bercorak burung merak dan hitam putih. Pemilik rumah berkata: "guci tidak bisa dilihat apabila acara ritual tidak berlangsung," 10

Tujuan datang ke rumah panggung hanya untuk silaturahmi dan berdoa untuk mencapai apa yang diinginkan. Adapun kegiatan makan bersama, sebelum makanan itu dimakan, makanan yang sudah diolah di rumah panggung di-bacabacai (doa-doa khusus) oleh dukun yang sering disebut sanro, dan sanro ini harus turun-temurun perempuan. Harus perempuan tidak boleh laki-laki, karena jika laki-laki untuk tradisi pa'ballea (pengobatan), dikarenakan Tupa'jaiyya adalah sanro pertama yang melakukan tradisi te'nea dan orang yang pertama tinggal di RW. Bajannang adalah seorang perempuan. Guci tersebut, sebagaimana pemaparan sebelumnya merupakan pusat titik pertemuan dari tradisi te'nea. Awalnya hanya dijadikan sarana pertemuan dan makan bersama.

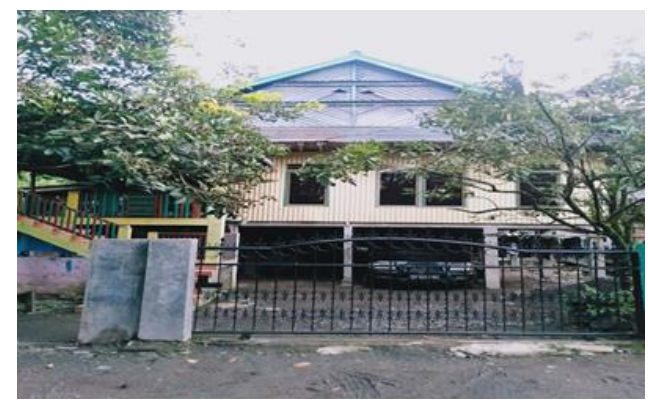

Gambar 1.2. Rumah Panggung Tempat Penyimpanan Guci Bernilai Sakral di Kec. Parigi.

Seiring berjalannya waktu, bertambah hal yang mesti dihadiri oleh pelaku tradisi

\footnotetext{
${ }^{10}$ Muhammad Sakri, Pemilik Rumah Panggung tempat Guci disimpan, (wawancara langsung pada tanggal 21 Februari 2020).
} 
te'nea yaitu mendatangi batang erasa (pohon beringin). Jadi, rute atau prosesi pelaku yang melakukan tradisi te'nea yakni pertama-tama ke bungung toa (sumur tua) untuk mencuci bahan makanannya seperti beras ketan berwarna hitam, putih, dan merah, ayam, kambing, sapi, atau kerbau. Kemudian diadakan masakmemasak di rumah panggung tempat guci tersebut. Terakhir berkunjung di batang erasa (pohon beringin). Di mana di dekat pohon beringin terdapat sebuah batu yang digunakan untuk meletakkan sesajen pada saat ritual berlangsung.

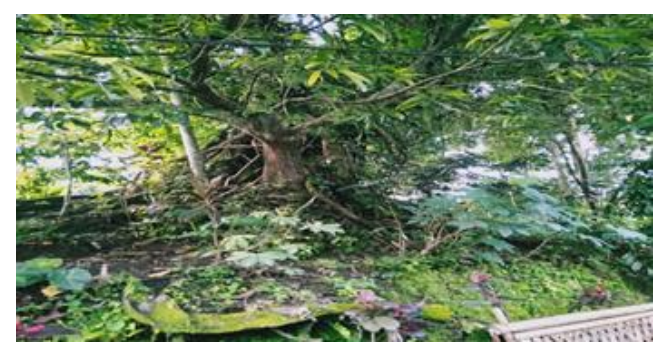

Gambar 1.3. Batang Erasa di Desa Majannang

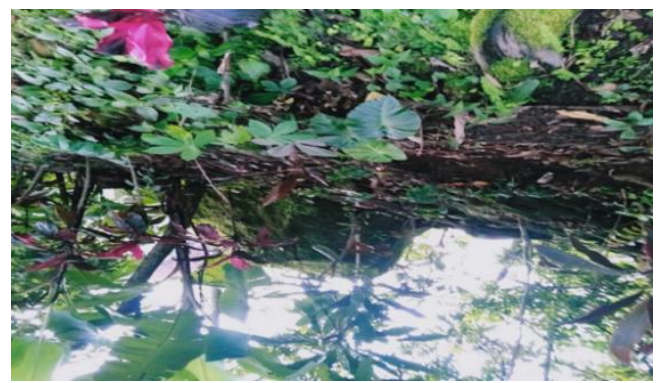

Gambar 1.4. Batu Tempat Peletakan Sesajen di Desa Majannang

Pelaksanaan tradisi te'nea, awal mulanya tidaklah dipatok diadakan pada hari tertentu. Belakangan ditetapkan hari khusus untuk pelaksanaan tradisi te'nea yaitu Senin dan Jumat. Adapun guci sakral hanya bisa dilihat pada saat acara berlangsung dan dalam tradisi ini dibutuhkan dupa untuk sanro.

Faktor Pendorong Masyarakat Desa Majannang, Kec. Parigi, Kab. Gowa Mengadakan Ritual Te'nea

Faktor pendorong atau alasan mendasar dilaksanakannya tradisi te'nea yaitu mengingat masa-masa nenek moyang terdahulu dan silaturahmi antar keluarga. Maksud lain diadakannya te'nea sebagai ajang musyawarah yang disebut rapat palili' yaitu musyawarah untuk membahas apa yang hendak dikerjakan untuk awal musim tanam, bibit apa yang disepakati untuk ditanam, sehingga meminimalisir serangan hama jika dilakukan bersama-sama. ${ }^{11}$ Acara ini telah dilaksanakan sejak dulu dan sudah turun temurun sampai sekarang. Namun, ditemukan terdapat beberapa masyarakat yang melakukan tradisi ini karena atau

\footnotetext{
${ }^{11}$ Sirajuddin Dg. Salle (Bapak Kepala Dusun Nirannuang) (wawancara langsung pada tanggal 21 Februari 2020).
} 
maksud dan tujuan lain seperti meminta kesembuhan, nazar, dan lain-lain. Sebagian lain menjadikannya sebagai pemanis dalam artian memperlancar usaha yang akan dilakukan, sebagaimana arti dari kata te'nea, itulah sebabnya tradisi ini dilaksanakan sebelum musim tanam. ${ }^{12}$

Awal mula pergeseran tradisi te'nea berlangsung manakala terjadi peristiwa kesembuhan pada penderita patah tulang kaki setelah berwudu dengan air dari bungung toa di RW. Putapela. Hal itu tampak dari penuturan Pemilik Rumah Panggung bercerita bahwa:

"Sekitar 4 tahun yang lalu, ada orang dari Limbung naik motor datang ke Bajannang, orang tersebut tidak bisa jalan sehingga dibawa ke sumur tua di Putepala. Lututnya dicuci sampai muka, setelah itu berwudu dan orang tersebut bisa kembali berjalan bahkan makan makanan berat, dan sesekali orang tersebut datang untuk silaturahmi ke Parigi."

Dari fenomena kesembuhan inilah yang merupakan faktor pendorong tradisi te'nea mulai mengalami pergeseran dan berkembang dengan maksud lain. Masyarakat memiliki pergeseran makna tradisi te'nea sebagai sarana memperoleh kesembuhan, nazar, pemanis, dan lain sebagainya.

\section{Perspektif Hukum Islam terhadap Pelaksanaan Tradisi Te'nea di Desa Majannang, Kec. Parigi, Kab. Gowa}

Perbuatan yang timbul yang berkaitan dengan hukum adat biasanya dilandasi dengan perasaan dan kesadaran hati. Sedangkan dalam hukum Islam pandangan senantiasa dilandasi dengan pertimbangan nas dari Alquran, Sunah, dan kesepakatan ulama (ijmak).

Berikut landasan syariat dalam menimbang hukum tradisi/ adat masyarakat di suatu daerah:

Dalam fiqh ada suatu kaidah yang menyebutkan,

${ }^{12}$ Supardi Lantara (Bapak Kepala Desa Majannang) (wawancara langsung pada tanggal 21 Februari 2020).

${ }^{13}$ Supardi Lantara (Bapak Kepala Desa Majannang) (wawancara langsung pada tanggal 21 Februari 2020).

${ }^{14}$ Ahmad bin Syekh Muhammad al-Rizqa, Syarh al-Qawaid al-Fiqhiyah (Dimasq: Dar al-Qalam 1989) h. 219 
Artinya "adat kebiasaan itu dapat dijadikan sebagai pijakan hukum". Jadi, apabila adat tersebut tidak melanggar dari syariat Islam dan juga tidak menjadikan mudarat bagi yang melaksanakannya maka sah untuk dilakukan.

Pada dasarnya syariat memandang bahwa hukum asal segala sesuatu diperbolehkan, khususnya dalam interaksi sesama manusia (muamalah), selama tidak ada dalil yang mengharamkan, sebagaimana dalam kaidah ushūl fiqh disebutkan bahwa;

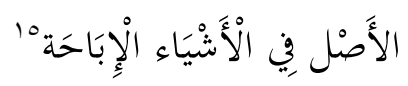

Artinya: "Hukum asal sesuatu dibolehkan."

Dalam pembinaan hukum fikih para imam mazhab banyak sekali memperhatikan adat istiadat ('urf setempat). Lebih jauh Imam Malik dalam membina mazhabnya menitikberatkan kepada 'amaliyah penduduk Madinah, yang menurut mazhab Imam Malik dapat dijadikan hujjah (landasan syariah), tentunya setelah Alquran dan Sunah yang sahih serta ijmak. ${ }^{16}$

Islam banyak yang dilandaskan pada penetapan hukum atas 'urf atau adat masyarakat, seperti dalam membedakan antara darah haid bagi wanita dengan darah istihadhah, salah satu metode yang digunakan adalah dengan memperhatikan durasi haid wanta disekitarnya. Contoh lain dalam penentuan mahar perkawinan, bagi laki-laki yang menikah tanpa menyebut mahar pernikahan maka jumlah maharnya dapat dipahami sesuai dengan adat kebiasaan setempat, kemudian diistilakan sebagai mahrun mitsly. ${ }^{17}$ Serta terdapat banyak lagi contoh aplikasi 'urf dalam syariat.

Tradisi te'nea yang awalnya bertujuan untuk silaturahmi sesama anggota keluarga, maka hal tersebut tidak bertentangan dalam Islam bahkan Nabi saw. menganjurkan hal tersebut, yaitu silaturahmi kepada keluarga yang masih memiliki hubungan darah seperti ayah, ibu, adik, kakak, dan saudara yang ada hubungan rahim.

Dalam hadits yang diriwayatkan oleh Imam Muslim, dari Abu Ayyūb al-Anshāri, dikatakan bahwa;

\footnotetext{
${ }^{15}$ Ahmad bin Syekh Muhammad al-Rizqa, Syarhu al-Qawāid al-Fiqhiyah, h. 481

${ }^{16}$ Kaukab Ubaid, Fiqh al-Ibadāt 'ala al-Mazhab al-Malikiyah (Dimasq: Matba' al-Insya' 1986), h.11

${ }^{17}$ Asma bin Abdullah al-Musa, Al-Urfu Hujjiyatuhu wa Atsaruhu al-Fiqhiyyah (Riyād: Al-Majjallah al-Arabiyah Li al-Dirasāt Amaniyah wa al-Tadrib t.th), h.44
} 


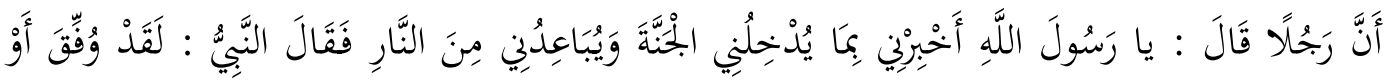

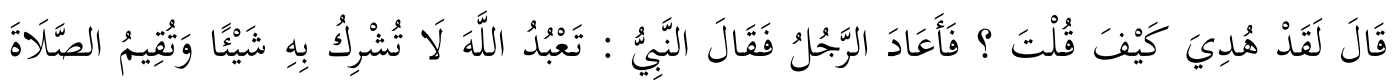

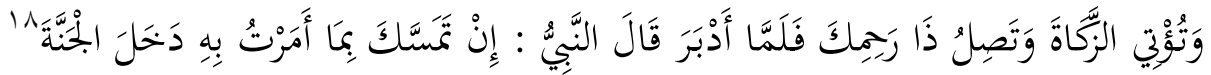

Artinya:

Bahwasanya seseorang berkata kepada Nabi saw.: "Wahai Rasulullah, beritahukanlah padaku tentang sesuatu yang dapat memasukkan aku ke dalam Surga dan menjauhkan aku dari Neraka?" maka Nabi saw. bersabda: "Sungguh dia telah diberi taufik," atau "Sungguh dia telah diberi hidayah, apa tadi yang engkau tanyakan?" Lalu orang it upun mengulangi perkataannya. Setelah it u Nabi saw. bersabda: "Engkau beribadah kepada Allah dan tidak menyekutukannya dengan sesuatu apapun, menegakkan salat, membayar zakat, dan engkau menyambung silaturahmi."

Terdapat pula beberapa keuntungan yang diperoleh bagi yang selalu menjaga silaturahmi agar tetap tersambung, hal itu meliputi:

1. Silaturahmi Bisa Memperpanjang Umur.

Berdasarkan hadits yang shahih yang diriwayatkan oleh Anas bin Mālik, bahwa Nabi bersabda:

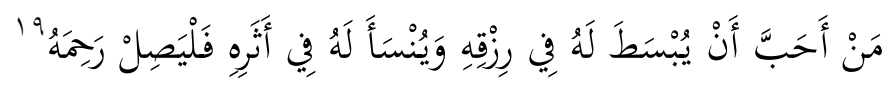

Artinya: "Barangsiapa suka dilapangkan pintu rizki untuknya dan dipanjangkan umurnya hendaknya ia menyambung tali silaturrahim."

2. Silaturahmi Bisa Memperlancar Rejeki

Berdasarkan hadis sahih dijelaskan bahwa;

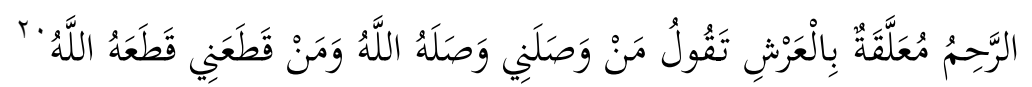

${ }^{18}$ Muslim bin al-Hajjāj al-Naisaburi, Șahīh Muslim (Bairūt: Dār Ihya Turāts al-Araby

${ }^{19}$ Muhammad bin Ismā'īil al-Bukhāri, Ṣaḥih al-Bukhāri, Vol 8 (Dimasq: Dār Tuq alNajāh 1422 H) h. 5.

${ }^{20}$ Muslim Muslim bin al-Hajjāj al-Naisaburi, Sahīh Muslim, Vol 4. h.1981 
Artinya: Al-Rahim itu tergantung di Arsy. Ia berkata, "Siapa yang menyambungku, maka pasti Allah akan menyambungnya, dan siapa yang memutuskanku, maka Allah akan memutus hubungan dengannya.

Dari beberapa hadis di atas, bisa disimpulkan bahwa acara-acara yang bertujuan hanya untuk silaturahmi maka dibolehkan bahkan dianjurkan, sedangkan tradisi membawa makanan untuk pemilik rumah dan dimakan bersama-sama pun tidak ada larangan sehingga hal seperti ini pun diperbolehkan sesuai dengan kaidah hukum asal segala sesuatu boleh, sampai ada dalil yang mengharamkannya.

Begitupula te'nea sebagai ajang musyawarah sejalan dengan syariat, dalam Islam musyawarah adalah sebuah amalan yang memiliki kedudukan yang sangat penting, terlebih kedudukan manusia sebagai makhluk sosial yang senantia berinteraksi dengan sesama manusia, karena maslahatnya yang begitu besar Allah memerintahkan untuk bermusyawarah, Allah berfirman dalam Alquran:

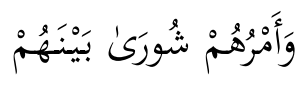

Terjemahnya:

"Sedang urusan mereka (diputuskan) dengan musyawarah antara mereka", (Q.S. al-Syuara/42: 38$)^{21}$

Ritual-ritual tertentu dalam tradisi te'nea berupa meminta kesembuhan, nazar kepada selain Allah, mensucikan benda-benda tertentu, menganggapnya dapat mendatangkan manfaat dan mencegah dari pada mudarat dan lain sebagainya telah menodai makna suci dari silaturahmi dan musyawarah yang merupakan tujuan awal dari tradisi te'nea, Sebagaimana yang dikemukan oleh Dg. Sibali:

"Pada dasarnya, itu orang-orang tua dulu maksudnya itu sebagai ajang silaturahmi, kemungkinan dibelakang ada masuk kepercayaan aliran-aliran dinamisme dan animisme yang melenceng pada apa yang diinginkan orang-orang dahulu $^{\text {,22 }}$

Oleh karena itu, segala macam persembahan seperti sesajen atau melakukan sesuatu ibadah kepada selain Allah swt. seperti memohon doa dan bernazar adalah perbuatan dosa yang sangat besar, bahkan merupakan perbuatan syirik besar yang bisa menyebabkan pelakunya keluar dari agama Islam.

Allah swt. berfirman,

\footnotetext{
${ }^{21}$ Al-Majid, Al-Qur'an Terjemah dan Tajwid Warna (Jakarta Pusat: Beras 2014) h.487

${ }^{22}$ Dg Sibali (Tokoh Agama) (wawancara langsung 21 Februari 2020).
} 


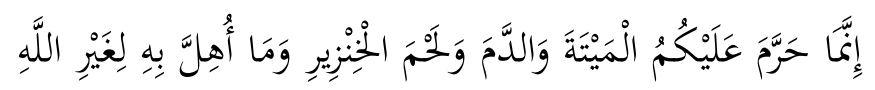

Terjemahnya:

"Sesungguhnya Allah hanya mengharamkan bagimu bangkai, darah, daging babi, dan sembelihan yang dipersembahkan kepada selain Allah." (Q.S. al-Baqarah/2: $173)^{23}$

Dalam sebuah hadis sahih, dari Ali bin Abi Tạalib ra., bahwa Rasulullah saw. bersabda:

$$
\text { لَعَنَ اللهُ مَنْ ذَبَحَ لِغَيْرِ اللهِ }
$$

Artinya: "Allah melaknat orang yang menyembelih (berkurban) untuk selainNya."

Hadis ini menunjukkan ancaman besar bagi orang yang menyembelih kepada selain Allah, dengan laknat-Nya yaitu dijauhkan dari rahmat-Nya. Karena perbuatan ini termasuk dosa yang sangat besar.

Nazar juga termasuk ketegori ibadah yang wajib diperuntukkan kepada Allah semata. Allah berfirman:

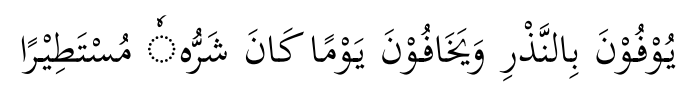

Terjemahnya: "Mereka memenuhi nazar dan takut akan suatu hari yang azabnya merata di mana-mana." (QS Al-Insa/76: 6)

Ayat ini menunjukkan bahwa nazar termasuk ibadah, sehingga tidak diperkenankan ditujukan kepada selain Allah, termasuk meyakini bahwa sesuatu yang dapat memberikan manfaat dan mencegah mudarat selain Allah juga berseberangan dengan prinsip tauhid, yaitu memurnikan beribadatan dan keimanan hanya kepada Allah, sebagaimana diisyaratkan oleh firman Allah:

$$
\text { وَاعْبُدُوا اللَّهَ وَلَا تُشْْرِكُوا بِِِ شَيْيًَا }
$$

Terjemahnya: "Sembahlah Allah dan janganlah kamu mempersekutukan-Nya dengan sesuatu apapun." (QS. Al-Nisa/4: 36). ${ }^{26}$

\footnotetext{
${ }^{23}$ Al-Majid, Al-Qur'an Terjemah dan Tajwid Warna, h.26

${ }^{24}$ Muslim bin al-Hajjij al-Naisaburi, Șahīh Muslim, Vol 3. h.1567.

${ }^{25}$ Al-Majid, Al-Qur'an Terjemah dan Tajwid Warna, h.579
} 
Olehnya itu perlu upaya maksimal para tokoh agama di desa Majannang untuk terus berdakwah dengan hikmah dan bertahap, serta bersinergi dengan pemerintah setempat untuk mengedukasi masyarakat akan maksud dan tujuan sebenarnya dari tradisi te'nea, dengannya masyarakat awam bisa memahami dengan baik urgensi silaturahmi dan musyawarah, serta memahami konsep tauhid agar terhindar dari segala macam praktek kesyirikan.

\section{KESIMPULAN}

Berdasarkan uraian di atas dapat disimpulkan bahwa tradisi te'nea merupakan tradisi turun temurun yang tidak diketahui asal muasalnya secara pasti. Tradisi ini pada awalnya terpusat pada dua tempat yaitu sumur untuk mencuci semua bahan yang akan di masak di rumah panggung tempat guci itu berada. Namun, lama-kelamaan tempat tradisi ini bertambah yaitu pohon beringin dan juga makam tempat Pajaiyya, orang yang pertama kali tinggal di kampung tersebut.

Awalnya tradisi ini hanya sebagai ajang silaturahmi antar keluarga serta sebagai ajang musyawarah antar tokoh masyarakat. Namun, lama-kelamaan berubah menjadi tradisi yang bertentangan dengan nilai-nilai Islam seperti adanya orangorang yang datang karena menginginkan kesembuhan, nazar, meyakini sebagai pemanis, dan lain-lain, yang mengandung kesyirikan. Pergeseran tradisi te'nea ini sangatlah fatal karena ditengarai mengandung kesyirikan yang berimplikasi pada haramnya tradisi ini dalam persperktif Hukum Islam. Namun jika unsur syirik dapat dihilangkan maka tradisi ini akan sejalan dengan ajaran silaturahmi yang sifatnya mustahab(dianjurkan).

\section{DAFTAR PUSTAKA}

Ahmad bin Syekh Muhammad al-Rizqa, Syarhu al-Qawā'id al-Fiqhiyyah (Dimasq: Dar al-Qalam 1989).

Asma bin Abdullah al-Musa, Al-'Urfu Hujjiyatuhu wa Atsaruhu al-Fiqhiyah (Riyad: Al-Majjallah al-Arabiyah Li al-Dirasat Amaniyah wa al-Tadrib t.th).

Bauto, L. M. (2014). Perspektif agama dan kebudayaan dalam kehidupan masyarakat indonesia (Suatu tinjauan sosiologi agama). Jurnal Pendidikan Ilmu Sosial, 23(2), 11-25.

Burga, M. A. (2019). Hakikat Manusia Sebagai Makhluk Pedagogik. AlMusannif, 1(1), 19-31.

Karim, A. (2017). Makna ritual kematian dalam tradisi Islam Jawa. Sabda: Jurnal Kajian Kebudayaan, 12(2), 161-171.

\footnotetext{
${ }^{26}$ Al-Majid, Al-Qur'an Terjemah dan Tajwid Warna, h.84.
} 
Kaukab Ubaid, Fiqh al-Ibadāt 'ala al-Mazhab al-Mālikiyah (Dimasq: Matba' alInsya' 1986), h.11

Lestari, G. (2016). Bhinnekha Tunggal Ika: Khasanah Multikultural Indonesia Di Tengah Kehidupan SARA. Jurnal Pendidikan Pancasila dan Kewarganegaraan, 28(1).

Al-Majid, Al-Qur'an Terjemah dan Tajwid Warna (Jakarta Pusat: Beras 2014).

Marinsah, S. A., Hamdan, M. N., Ariffin, M. F. M., \& Ramli, M. A. (2016). Amalan tradisi masyarakat Bajau di Semporna Sabah: kajian menurut hukum Islam. Perspektif: Jurnal Sains Sosial dan Kemanusiaan, 8(2), 135-149.

Muhammad bin Isma'ìl al-Bukhāri, Șahīh al-Bukhāri, Vol 8 (Dimasq: Dar Tuq al-Najah $1422 \mathrm{H})$.

Mujib, M. M. (2016). Fenomena Tradisi Ziarah Lokal dalam Masyarakat Jawa: Kontestasi Kesalehan, Identitas Keagamaan dan Komersial. IBDA: Jurnal Kajian Islam dan Budaya, 14(2), 204-224.

Muslim bin al_Hajjāj al-Naisaburi, Șahīh Muslim (Bairut: Dar Ihya Turas alAraby t.th).

Muslim bin al_Hajjāj al-Naisaburi, Șahih Muslim, Vol 3. h.1567.

Muslim bin al_Hajjāj al-Naisaburi, Șahīh Muslim, Vol 4. h.198.1

Nurdin, A. (2016). Integrasi Agama dan Budaya: Kajian Tentang Tradisi Maulod dalam Masyarakat Aceh. EL HARAKAH (TERAKREDITASI), 18(1), 45-62.

Wagianto, R. (2017). Tradisi Kawin Colong Pada Masyarakat Osing Banyuwangi Perspektif Sosiologi Hukum Islam. Al-Ahwal: Jurnal Hukum Keluarga Islam, 10(1), 61-84. 